\title{
Inter- and Intra-firm Learning Synergy through Integrating Absorptive Capacity and Employee Suggestion Processes: A Case Study of the Firm Frauenthal Automotive Toruń
}

\section{Andrzej Lis ${ }^{1}$ and Agata Sudolska ${ }^{2}$}

\begin{abstract}
The aim of the paper is to study relationships between the processes of absorptive capacity (inter-firm learning) and learning lessons through employee suggestions (intra-firm learning) and identify potential synergies between them. The research interest is focused on investigating the following problems: (1) How do organizations apply external knowledge to support intra-organizational learning processes? (2) How should the employee suggestion system be organized to increase (or build) absorptive capacity? The exploratory case study analysis is applied to answer research questions and achieve the aim of the study. The unit of analysis is constituted by inter-firm and intra-firm learning processes observed in the firm Frauenthal Automotive Torun (FTO).

Keywords: organizational learning; absorptive capacity; lessons learned; employee suggestion system.
\end{abstract}

\section{INTRODUCTION}

Due to the fact that nowadays knowledge is treated as one of the most suitable resources to build a firm's competitiveness (e.g. Barlow \& Jashapara, 1998; Zahra \& George, 2002; Adams \& Lamont, 2003; Rhodes, Lok, Yu-Yuan Hung \& Fang, 2008; Beyer, 2011), in the contemporary competitive business environment the ability to learn becomes the priority of any ambitious company. Today, there is no doubt that the challenges of business reality require constant development of a firm's ability to integrate different kinds

1 Andrzej Lis, Ph.D., The Faculty of Economic Sciences and Management, Nicolaus Copernicus University, ul. Jurija Gagarina 13a, 87-100 Toruń, Poland, e-mail: andrzejlis@econ.umk.pl.

2 Agata Sudolska, dr hab., prof. UMK, The Faculty of Economic Sciences and Management, Nicolaus Copernicus University, ul. Jurija Gagarina 13a, 87-100 Toruń, Poland, e-mail: aga@econ.uni.torun.pl. 
of knowledge, and to coordinate its usage, leading to valuable commercial outcomes (cf. Czerniachowicz, 2003; Beyer, 2012). Taking this into account, we assume that the enhancement of a firm's ability to learn, both through intra- and inter-firm learning, is a prerequisite for business success (in terms of its innovativeness and competitiveness).

Organizational learning is a process combining knowledge and change management, which results in cognitive and behavioral changes in an organization. The construct of organizational learning includes a variety of learning processes encompassing the areas of knowledge acquisition, information distribution, information interpretation and organizational memory (Huber, 1991). Learning processes may be sourced from external information and knowledge, as well as relying on knowledge developed internally by organization members. Inter-organizational learning requires a company to have an absorptive capacity which is defined as "the ability of a firm to recognize the value of new, external information, assimilate it, and apply it to commercial ends" (Cohen \& Levinthal, 1990, p. 128) or "a set of organizational routines and processes by which firms acquire, assimilate, transform and exploit knowledge to produce a dynamic capability" (Zahra \& George, 2002, p. 186). We assume the comprehensive view of the construct of absorptive capacity which consists of processes, routines and schemes, however, in our paper we will focus the research attention on the process of absorptive capacity due to the process-oriented perspective we applied in the study. Learning lessons from the experience of organization members is an example of intra-organizational learning processes supporting organizational efforts for continuous improvements. As pointed out by Garvin (1993), a successful continuous improvement program requires organizational commitment to learning. Combining all three constructs together, we may assume that absorptive capacity builds on the foundations of organizational learning, while implementing employee suggestion programs can be considered as an example of organizational routines and processes increasing the firm absorptive capacity ${ }^{3}$.

Sun and Anderson (2010) examine the nature of relationships between absorptive capacity and organizational learning and they argue that absorptive capacity and organizational learning concepts share conceptual affinity. We take an assumption of the argument made by these authors that "ACAP [absorptive capacity] should be considered as a specific type of OL [organizational learning] which concerns an organization's relationship with external knowledge" (Sun \& Anderson, 2010, p. 141). Similarly, Lis (2016) proves that the lessons learned process can be considered as an example of organizational learning processes and it follows the 41 model of organizational

3 The authors are grateful to the anonymous reviewer for this suggestion. 
learning proposed by Crossan, Lane and White (1999). If both absorptive capacity and learning lessons through employee suggestion systems share conceptual affinity with organizational learning processes, then searching for links and synergies between both concepts seems to be something natural. The aim of this paper is to study relationships between the processes of absorptive capacity (inter-firm learning) and learning lessons through employee suggestions (intra-firm learning) and identify potential synergies between them. In particular, the research interest is focused on investigating the following problems:

- How do organizations apply external knowledge to support intraorganizational learning processes?

- How should the employee suggestion system be organized to increase (or build) absorptive capacity?

In order to explore the aforementioned relationships the qualitative approach focused on the case study analysis is applied. Inter-firm and intrafirm learning processes observed in Frauenthal Automotive Torun (FTO) are the unit of analysis. The details concerning the sampling process, data collection and analysis are provided further in the section "Method of the study".

In our study, we adopt a position of methodological individualism as we support the claim that "social phenomena must be explained by showing how they result from individual actions, which in turn must be explained through reference to the intentional states that motivate individual actors" (Heath, 2015). According to the ontological claims to the methodological individualism, only individuals exist, all organizations consist of individuals (members), and organizations act through individuals (Kincaid, 2004, p. 301). We assume that the study of organizational learning processes is in line with the aforementioned statements. When considering the issue of organizational learning, it must be emphasized that only individuals can learn actively. Due to this, organizational learning is derived from transformation of individual knowledge into a firm's memory and routines (Mäkinen, 2002). As highlighted by Yli-Renko (1999), a company learns while any of its units or employees acquires knowledge recognized as useful to the firm's operations, which leads to potential behavior change. The significance of linking individual, group and organizational levels of learning is stressed also by Crossan, Lane and White (1999).

The paper consists of two parts: the theoretical grounding and the empirical research based on case study methodology. In the theoretical part, first of all, the idea and the process of organizational learning are examined. Secondly, the concept of absorptive capacity is discussed. Thirdly, the employee suggestion systems and the lessons learned methodology 
are analyzed. Finally, the affinity between absorptive capacity and learning lessons through employee suggestion systems is explored. The literature review builds up the foundation for the empirical research. The empirical part of the paper starts with the presentation of the method of the study and the context of the study. Then, the paper explores the possibility to use external knowledge in support of the lessons learned process, triggered by employee suggestions. Finally, it discusses the role of employee suggestion systems to strengthen the company's absorptive capacity.

\section{THEORETICAL GROUNDING}

\section{Organizational learning}

Organizational learning is considered to be one of the key aspects of the knowledge management concept. In his model of knowledge management, Jashapara (2004, p. 12) enumerates organizational learning together with strategy, culture, and system and technology, among the dimensions of knowledge management in contemporary organizations. Organizational learning has been conceptualized in a variety of ways and there are numerous discussions concerning its nature and attributes. The lack of convergence is observed in the literature whether learning processes should be conscious and intentional, whether learning should always affect organizational effectiveness and whether it should result in behavioral changes (Huber, 1991, pp. 88-89).

As observed by Dodgson (1993), the construct of organizational learning is studied from various perspectives including: economic history, industrial economics, the theory of the firm and strategic management. The debate between the proponents of economic and behavioral perspectives contributed to the emergence and development of the concept of organizational learning (Olejniczak, Płoszaj \& Rok, 2012; Olszewska, 2013; Jaskanis, 2016). Taking into account the aforementioned divergences in research findings and opinions, for further analysis the behavioral perspective will be applied i.e. we assume that organizational learning is a construct combining knowledge management processes (cognitive change) and change management processes (behavioral change). The choice of the behavioral perspective is motivated by the focus of our study on mechanisms and processes of learning, their antecedents and outcomes, and the role of relationships for learning processes.

According to Fiol and Lyles (1985), who follow the behavioral perspective, organizational learning is "the process of improving actions through better knowledge and understanding" (Fiol \& Lyles, 1985, p. 803). In the literature there is a dispute whether organizational learning changes 
actual or potential behaviors of an organization. Some researchers argue that organizational learning results in a change of a firm's actual behavior (e.g. Garvin, 1993; Holmqvist, 1999; Holmqvist, 2000). Garvin (1993, p. 80) highlights that, organizational learning refers to creating, acquiring and transferring knowledge for improved firm's actions. Some other researchers (Huber, 1991; Yli-Renko, 1999) perceive organizational learning as a change in the range of a firm's potential behaviors. Huber (1991, p. 89) claims that "[a]n entity learns if, through its processing of information, the range of its potential behaviors is changed". Despite differences in various approaches to define organizational learning, we can state that it combines the potential of knowledge with the efforts for the improvement and development of an organization.

Huber (1991) who applies the process-oriented perspective to study the phenomenon of organizational learning, identifies the set of processes and constructs which constitute organizational learning. His model includes: knowledge acquisition, information distribution, information interpretation and organizational memory. Due to the area of interest of the paper, special attention should be given to the process of knowledge acquisition which incorporates: congenital learning, experiential learning, vicarious learning, grafting knowledgeable individuals and organizations, and searching and noticing. The issues of learning from other organizations (vicarious learning) as well as searching and noticing external knowledge are associated with the concept of absorptive capacity to be explored in our study. Similarly, the concepts of lessons learned and employee suggestion systems share affinity with the assumptions of experiential learning.

Following the methodological individualism approach and assuming that all the processes of inter-firm and intra-firm learning occur through learning by individuals (organization members), the roles of organizational culture and knowledge signification (giving meaning to new knowledge) should be emphasized. The extraordinary role played by a learning culture is visible in the cases of both absorptive capacity and employee suggestion systems. As highlighted by Schein (2004), organizational culture directly refers to learning processes as it is defined by him as "a pattern of shared basic assumptions that was learned by a group as it solved its problems of external adaptation and internal integration, that has worked well enough to be considered valid and therefore to be taught to new members as the correct way to perceive, think and feel in relation to those problems" (Schein, 2004, p. 17). The approach presented by Schein underlies that organizational culture develops while knowledge is created on the level of enterprise assumptions. An organizational culture supporting learning strongly focuses on trust and interaction between employees, friendly relationships between co-workers, 
efficient communication that gives employees the feeling of being listened to as well as the feeling of belonging and worth. Such values emphasized by a firm enable it to create a healthy environment fostering creativity, cooperation and knowledge exchange (Isaken, Lauer, Ekvall \& Britz, 2001; Vera \& Crossan, 2004; Freiling \& Fichtner, 2010). As highlighted by several researchers, employees' teams characterized by a high ability to cooperate among team members and a trust in each other, deliver a better performance compared with the teams lacking good interpersonal relationships (Davidson \& James 2007; Rowe \& Guerrero, 2011). It results from the presence of discussion among employees and confronting different points of view. To behave this way, employees need to feel free while expressing their opinions, even if they are critical. However, people are open to a constructive exchange of critical feedback if they feel safe and rely on positive relationships and trust within a company. In turn, feeling safe and comfortable, they are more likely to take others' criticism and negative feedback as opportunities to learn and change. Moreover, according to the reference literature, learning culture strongly focuses on a self-motivated view of people and thus provides employees with challenging tasks and a wide range of freedom while performing, as well as leadership that allows risk-taking, experimentation and thus making mistakes. This means that organizational culture supporting learning processes involves tolerance for uncertainty and ambiguity in the workplace. Having such leaders, employees are not afraid of sharing ideas even if they are not perfectly sure about them (Ekvall 1996; Goleman, Boyatzis \& McKee, 2000; Isaken et. al, 2001, Freiling \& Fichtner, 2010).

Consolidating the study on learning cultures from the process-oriented perspective, Freiling and Fichtner (2010, pp. 161-166) identify the features of organizational cultures conducive to the components of the extended model of the organizational learning process. The catalogue includes:

- intuiting - "high willingness to actively shape the environment", "high willingness to interact with each other", "a self-motivated view on people", and "clear-cut mission and primary task";

- absorbing - "pragmatic orientation of people" and "the view that people are self-motivated";

- interpreting - "clear and common communication system", "leaders asking their employees for input"; "high ability to handle ambiguity" and "clear mission";

- integrating - "high willingness for discussion" and "informal internal coordination";

- institutionalizing - "flat hierarchy" and "clear mission and primary task".

In considering the processes of inter-firm and intra-firm learning, the issue of knowledge signification should be focused on. Due to the fact that 
knowledge signification means giving meaning to new knowledge, it directly refers to the communication system within a firm. Knowledge signification concerns communicating to the employees why new knowledge is valuable, how it is linked to prior knowledge, how it is going to develop a whole company's body of knowledge, and how it can be used to deliver new values. It also refers to communicating to an organization's members, how the firm, and thus individual employees, will benefit from the new knowledge. Taking into account the nature of knowledge signification it can be treated not only as an aspect of a communication system within a company but also as one of the leadership aspects. It is indisputable that the ability and efficiency in giving meaning to new knowledge is a prerequisite for enhancing employees' activities concerned with learning (Nonaka, Toyama \& Konno, 2000; Jonassen \& Land, 2012).

Crossan et al. (1999) propose the 4 I framework of organizational learning, consisting of interrelated processes of intuiting, interpreting, integrating and institutionalizing, observed at the individual, group and organizational level. Learning processes starting from intuiting and going through interpreting and integrating to institutionalizing are considered as feed forward, while the reverse direction (i.e. from institutionalizing to intuiting) is labeled as feedback. The process of organizational learning based on the $4 \mathrm{l}$ model is presented in Figure 1.

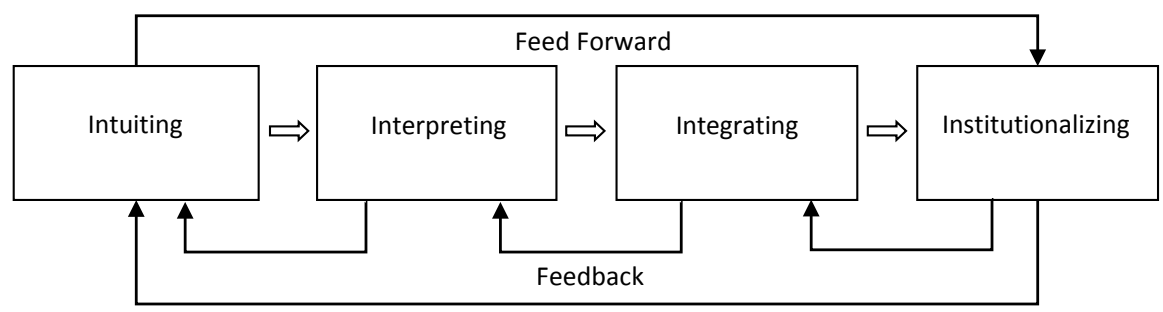

Figure 1. The process of organizational learning

Source: Authors' work based on Crossan, Lane \& White (1999).

Intuiting, which occurs at the individual level, is defined as "the preconscious recognition of the patterns and/or possibilities in a personal stream of experience" (Crossan et al., 1999, p. 525; cf. Weick, 1995, p. 25). The foundation for intuiting is personal experience of an expert or an entrepreneur who express their feelings through images or metaphors, which leads to the process of interpreting. Interpreting means "the explaining, through words and/or actions, of an insight or idea to one's self and to others" (Crossan et al., 1999, p. 525). In the process of interpreting, organization members 
develop their cognitive maps, and through conversation and dialogue build a shared understanding. Interpreting bridges both individual and group learning. Integrating, which occurs at the group level and the organizational level, is "the process of developing shared understanding among individuals and of taking coordinated action through mutual adjustment" (Crossan et al., 1999, p. 525). Institutionalizing, which takes place at the organizational level, is "the process of ensuring that routinized actions occur" (Crossan et al., 1999, p. 525). Through institutionalizing, the actions which produced positive outcomes become routines and then, when they are validated through diagnostic systems, develop into rules and procedures.

What should be emphasized is that the $4 \mathrm{l}$ model combines the aforementioned feed-forward processes with feedback processes of learning, which are used to exploit institutionalized knowledge in order to change the way of thinking and behavior of individuals and teams in an organization. As assumed by Crossan et al. (1999, p. 532), feedback learning processes begin at the organizational level (institutionalizing) and go on to the individual level (intuiting). However, as Freiling and Fichtner (2010, p. 160) claim, it has not been detailed which learning processes are included in the feedback loop and they make the proposal that the feedback consists of interpreting and integrating. As regards the feedback, Crossan et al. (1999, p. 532) point out the tension between exploration (feed forward) and exploitation (feedback). One of its consequences is the threat of driving out intuiting processes by institutionalized knowledge which may create barriers for innovative thinking and block the assimilation of new learning. It means that both individuals and organizations show tendencies to stick to outdated institutionalized knowledge. In order to mitigate such risks, the issue of unlearning should become a part of organizational practices. Unlearning is defined as "a process through which learners discard knowledge" (Hedberg, 1981, p. 18; quoted after Huber, 1991, p. 104) or "the process of reducing or eliminating preexisting knowledge or habits that would otherwise represent formidable barriers to new learning" (Newstrom, 1983, p. 36). However, unlearning has both positive and negative effects. On the one hand, the unlearning process makes an 'empty space' for new knowledge but on the other hand an organization remains temporarily inactive (cf. Huber, 1991, pp. 104-105).

The $4 \mathrm{I}$ model focuses its attention on the intra-organizational learning processes and does not include the aspects of inter-firm learning which is crucial from the perspective of this study. Such a fact should be considered as a limitation for the applied research framework ${ }^{4}$. However, this weakness is mitigated by the extended version of the model proposed by Freiling and Fichtner (2010) who point out that knowledge generated within

4 The authors are grateful to the anonymous reviewer for this observation and their suggestions. 
an organization is supplemented with knowledge absorbed from the environment. In consequence, Freiling and Fichtner (2010, p. 161) add to the $4 \mathrm{l}$ model the process of absorbing knowledge which occurs at the level of individual learning and makes a bridge between intra-organizational learning and the absorptive capacity.

According to several researchers, organizational learning may take place because firms make efforts to fill their knowledge gaps. It is observed that companies increasingly rely on external sources of knowledge to extend their knowledge assets to foster innovation and enhance performance (Haider, 2003; Lichtenthaler, 2009). Today, it is indisputable that a firm's ability to learn faster than its competitors is the only form of sustainable competitive advantage that entities of an entrepreneurial orientation have: and by focusing on being innovative and emphasising organisational learning as a way to discover something new that can bring added value, it allows them to strengthen their competitiveness (de Geus, 1988; Davenport \& Prusak, 2000; Rhodes et al., 2008). Certainly, a company has a choice - it may create necessary knowledge itself (e.g. through intensive R\&D activities) or may acquire desired knowledge from outside. However, even in the case of acquiring new knowledge, a firm needs an absorptive capacity to make use of this new knowledge in order to apply it to commercial ends. Taking into account the above, we can state that a firm's knowledge base is derived both from its managers and employees individual knowledge enhancement and a firm's embeddedness in various inter-firm relationships established in the market.

\section{Absorptive capacity}

Nowadays, there is considerable agreement between researchers on the view that inter-firm learning, through knowledge transfer or common creation of new knowledge necessary to sustain a firms' competitiveness, is a frequent reason for establishing inter-firm relationships. Inter-firm learning means learning by organizations having both formal business relationships such as strategic alliances, collaborations with suppliers and distributors or licensing agreements (Larsson, Bengtsson, Henriksson \& Sparks, 1998) and informal contacts with business partners, trade fairs exhibitors, inter-firm platforms users etc. The expansion and complexity of knowledge increases rapidly nowadays, making it very difficult for a single company to contain and capitalize on all the relevant knowledge. Thus, firms operating in such a reality need to utilize business partnerships, boundary-spanning personnel, and other policies of inter-firm cooperation to increase their absorptive capacity (Anderson, Forsgren \& Holm, 2001; Lane, Koka \& Pathak, 2006; 
Palakshappa \& Gordon, 2007). Inter-firm learning is perceived as an extension of organizational learning, developing enterprise knowledge and providing new insights into the firm's strategy (Mohr \& Sengupta, 2002). The process of inter-firm learning involves acquiring, disseminating, interpreting, using and storing the information within or across the firm which leads to creating knowledge that strengthens a firm's innovativeness and competitiveness (Sudolska \& Lis, 2014). However, companies need absorptive capacities in order to combine external knowledge with their internal knowledge bases and produce positive outcomes.

The concept of absorptive capacity was first proposed by Cohen and Levinthal (1990) who use this term to label a firm's capability to innovate and thus be dynamic. The issue of absorptive capacity is studied both at the macro- and micro-economic level. A review of literature on the nation-level analysis of absorptive capacity is provided among others by Narula (2003) or Crisculo and Narula (2008). However, the focus of this paper is exclusively on the firm absorptive capacity.

According to Cohen and Levinthal absorptive capacity consists of "the ability of a firm to recognize the value of new, external information, assimilate it and apply it to commercial ends" (Cohen \& Levinthal, 1990, p. 128). Absorptive capacity is described as the collective ability of a firm resulting from individual abilities of its members whose prior knowledge and experience provide the ability to recognize new information, assimilate it and create value out of it (Cohen \& Levinthal, 1990; Sun \& Anderson, 2010). Cohen and Levinthal (1990) propose that (the process of) absorptive capacity involves three key elements (stages): recognizing the value of new information, assimilating that information and applying it to commercial ends (cf. Figure 2).

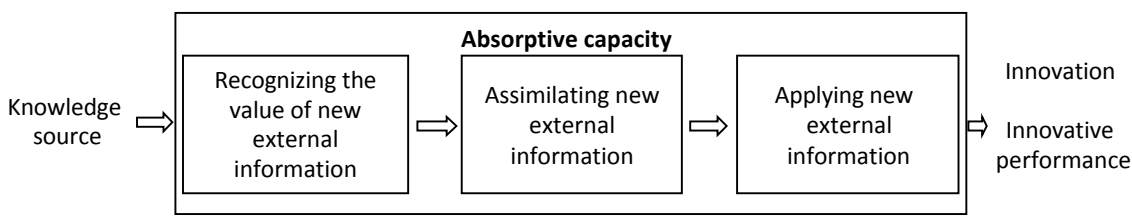

Figure 2. The absorptive capacity process based on the Cohen and Levinthal approach

Source: Authors' work based on Cohen and Levinthal (1990).

Since the concept of absorptive capacity was first proposed by Cohen and Levinthal (1990), subsequent researchers have given it extensive attention. Zahra and George (2002, p. 186) who reconceptualize the absorptive capacity concept argue that it is "a set of organizational routines and processes by 
which firms acquire, assimilate, transform and exploit knowledge to produce a dynamic capability". According to their approach, absorptive capacity (process) encompasses four components (stages): knowledge acquisition, knowledge assimilation, knowledge transformation and knowledge exploitation. Zahra and George (2002) combine these components into two subsets with different value-creating potentials: potential absorptive capacity (involving knowledge acquisition and assimilation) and realized absorptive capacity (involving knowledge transformation and exploitation) (cf. Figure 3).

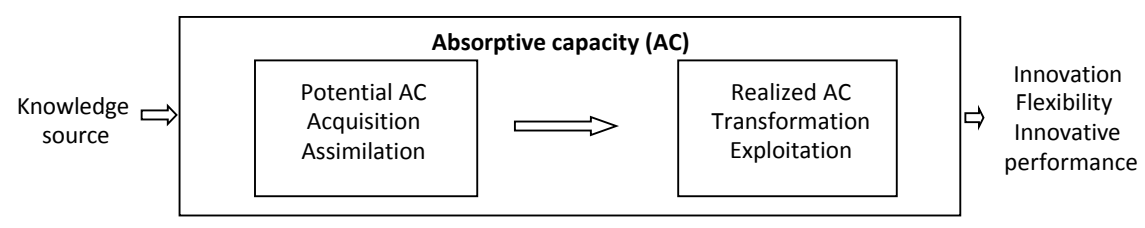

Figure 3. The absorptive capacity process based on the Zahra and George approach

Source: Authors' work based on Zahra and George (2002).

In the Zahra and George (2002) approach, knowledge acquisition "refers to a firm's capability to identify and acquire externally generated knowledge that is critical to its operation". Knowledge assimilation is described as "the firm's routines and processes that allow it to analyze, process, interpret and understand the information obtained from external sources". As far as knowledge transformation is concerned, Zahra and George perceive it as "a firm's capability to develop and refine the routines that facilitate combining existing knowledge and the newly acquired and assimilated knowledge". Finally, knowledge exploitation is defined as "the routines that allow firms to refine, extend and leverage existing competencies or to create new ones by incorporating acquired and transformed knowledge into operations" (Zahra \& George, 2002, pp. 189-191).

While deliberating the issue of absorptive capacity, it is important to stress that the Zahra and George (2002) conceptualization is criticized by some researchers e.g. Todorova and Durisin (2007) who call for reintroducing the elements of the original Cohen and Levinthal (1990) concept. According to Todorova and Durisin (2007) knowledge assimilation and knowledge transformation should be treated as two alternative, not sequential, processes as proposed by Zahra and George (2002). Todorova and Durisin also criticize distinguishing between potential and realized absorptive capacity, maintaining that the definitions of these two subsets of absorptive capacity components are ambiguous and unclear. Referring to the aforementioned 
deliberations, we propose to illustrate the reconceptualized process of absorptive capacity in Figure 4.

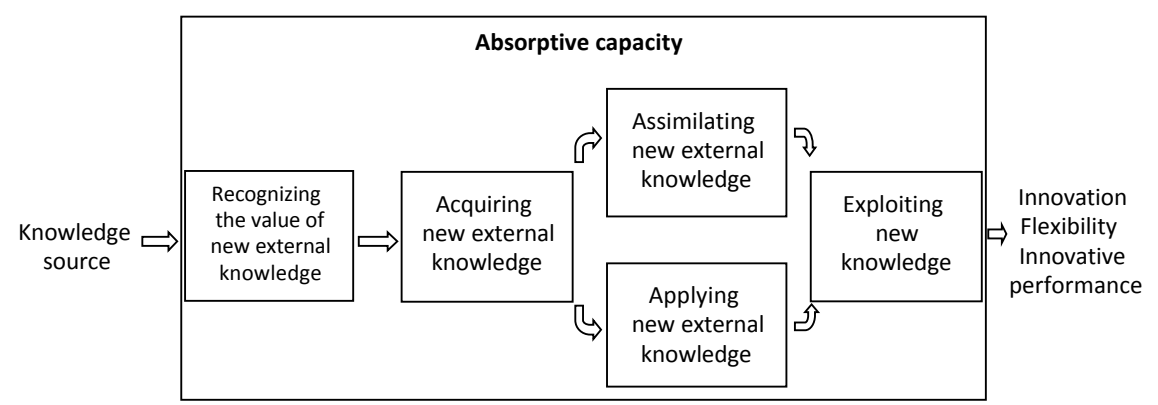

Figure 4. The absorptive capacity process based on the Todorova and Durisin approach

Source: Authors' work based on Todorova and Durisin (2007).

Taking into account the above presented approaches concerning the components (stages) of the absorptive capacity process, we assume that despite differences in distinguishing particular absorptive capacity elements, the heart of the issue is the same in all researchers' approaches. Absorptive capacity is a process of developing a firm's knowledge base through relations with outside sources and therefore leading to strategic change, responding to specific environment requirements, and thus to renewal of a company.

In literature, there are numerous studies aimed at identifying the antecedents and enhancers of absorptive capacity. The examples include:

- Cohen and Levinthal (1990): firm prior knowledge and experience, R\&D investments, individual employees absorptive capacity and communication system;

- Zahra and George (2002): exposure to diverse and complementary sources of knowledge, firm experience, social integration mechanisms and regimes of appropriability;

- Sun and Anderson (2010): type of intuition represented by organization members who receive external knowledge, dialogue, diversity of team members' experience, environment supporting innovativeness, ambidextrous leadership, reward and recognition mechanisms and effective allocation of organizational resources.

Summing up, we appreciate and recognize as the most comprehensive the model of the absorptive capacity process based on the Todorova and Durisin (2007) approach presented in Figure 4. Nevertheless, we develop the assumptions of our study on the Sun and Anderson (2010) model of affinity between the processes of absorptive capacity and organizational 
learning which is based on the Zahra and George (2002) reconceptualization of absorptive capacity. Therefore, we will use the Zahra and George (2002) model of absorptive capacity including such components as: acquisition, assimilation, transformation and exploitation.

\section{The process of learning through employee suggestions}

Employee suggestion systems are traditionally associated with Total Quality Management and Kaizen in particular (Imai, 2012). Nevertheless, an interesting resemblance may be observed between employee suggestion systems and lessons learned systems which are the examples of organizational learning. The similarities between the two aforementioned systems are manifested in their definitions, aims and processes.

Discussing an employee suggestion system, van Dijk and van den Ende (2002) refer to the definition provided by Ekval (1971) who characterizes it as "an administrative procedure for collection, judging and compensating ideas, which are conceived by employees of an organization" (van Dijk \& van den Ende, 2002, p. 387). Lessons learned systems are defined as "knowledge management (KM) initiatives structured over a repository of lessons learned (LL). Lessons learned are knowledge artifacts that convey experiential knowledge that is applicable to a task, decision, or process such that, when reused, this knowledge positively impacts an organization's results" (Weber \& Aha, 2003, p. 287).

As observed by van Dijk and van den Ende (2002, p. 387) "[f]rom a perspective of knowledge development and diffusion in the firm, suggestion systems aim at capturing good ideas, the first part of the "knowledgebrokering cycle' (Hardagon \& Sutton, 2000), and they are an example of externalization of knowledge (Nonaka \& Konno, 1998; Nonaka \& Takeuchi, 1995)". Lessons learned processes are considered to be the examples of knowledge externalization processes, too (Girard, 2004, pp. 22-23; Lis, 2014a, pp. 66-67). Similarly, the aim of lessons learned is to externalize the experiential knowledge of organization members and use it for improving an organization. For instance, as officially declared in military publications (NATO doctrine in this particular case), the aim of the Lessons Learned procedure is "to learn efficiently from experience and to provide validated justifications for amending the existing way of doing things, in order to improve performance, both during the course of an operation and for subsequent operations" (AJP3(B) 2011, p. 4.19).

Neagoe and Marascu Klein (2010) point out four components of the employee suggestion cycle: encouraging employees to participate in the system, motivating them to write proposals, processing proposals (i.e. 
reviewing them, evaluating and implementing validated ideas), and awarding payments and commendations. Focusing on learning processes Van Dijk and van den Ende (2002, p. 389) enumerate three following stages of the employee suggestion process: idea extraction, idea landing and idea followup. Idea extraction focuses on externalizing employee tacit knowledge and transforming it into explicit knowledge. Then, the knowledge externalized in the process of idea extraction is assimilated by an organization in the stage of idea landing. Finally, the submitted idea is processed and turned into innovations in the process of idea follow-up. As regards lessons learned, Milton (2010, pp. 16-20) indicates three steps in the lessons learned cycle: identifying lessons, assigning actions to resolve issues and institutionalizing the changes in an organization. The process of lesson identification is achieved through reviewing the experience of organization members, analyzing submitted observations and generalizing in order to propose conclusions and recommendations for change. A lesson identified, being an outcome of aforementioned operations is defined as "a recommendation based on analyzed experience (positive or negative) from which others can learn in order to improve their performance on a specific task or objective" (Milton, 2010, p. 17). As such, the process of lessons identification can be considered as an example of cognitive change in an organization. Assigning action is the second step in the lessons learned cycle. A lesson is not learned until the change is implemented, which means that cognitive change mentioned above must be followed by behavioral change to close the loop of learning lessons. According to such a way of thinking a lesson learned is defined as "a change in personal or organizational behavior as a result of learning from experience" (Milton, 2010, p. 16). The third step of the lessons learned cycle is labeled as institutionalization of lessons which focuses on disseminating lessons in an organization through broadcasting them via the channels of intra-organizational communication, and training and educating employees.

Fairbank and Williams (2001) claim the employee suggestion systems require supporting technology to encourage employee motivation to participate in such programs. They assume that an effective employee suggestion system technology should be founded on enhancing three pillarsi.e. employee expectancy (employee feeling that they are competent enough to participate in the program), instrumentality (receiving appropriate feedback) and valence (offering attractive rewards). In their Creativity Transformation Model, Van Dijk and van den Ende (2002) identify organizational culture and structures as the key organizational success factors for the implementation of effective employee suggestion systems. Discussing how the aforementioned antecedents influence the processes of employee suggestion, they point out the roles of: "encouragement" by organizational culture at the stage of idea 
extraction, "organizational support" from organizational culture and structure for idea landing and "committed resources" being a part of organizational structure for idea follow-up. The detailed items included into the Creativity Transformation Model are (Van Dijk \& van den Ende, 2002):

- encouragement: "alignment", "possibility of reflection" and "emanation of idea receptiveness";

- organizational support: "idea receptiveness", "accessibility of the system" and "broadness of scope";

- committed resources: "intensity of evaluation", "use of rewards" and "processing of ideas".

Employee suggestion programs and lessons learned capabilities rely on the willingness of organization members to externalize their knowledge and share it with others. Therefore, effective reward systems, as well as organizational culture and a climate encouraging positive employee behaviors manifested in sharing knowledge, are considered to be the antecedents of paramount importance for the efficiency and effectiveness of such intrafirm learning processes (Van Dijk and van den Ende, 2002; Lis, 2012a, 2012b, 2014b; Marksberry, Church \& Schmidt, 2014). Organizational culture conducive to employee suggestions programs and lessons learned processes should be oriented to creating organizational conditions and encouraging knowledge transfer, and to learning from both organizational failures and successes (Edmondson, 2007; Kazojć, 2013).

\section{In search of synergy between inter- and intra-firm learning}

As discussed earlier, the ability to identify and recognize the value of external knowledge is the first step in developing a firm's absorptive capacity. However, the ability to recognize the desired knowledge is the outcome of a firm's competences resulting from its prior related knowledge. As highlighted by many authors, most companies with a high level of receptivity to new knowledge are at the same time very successful in learning (e.g. Cohen \& Levinthal, 1990; Child, Faulkner \& Tallman 2005; Trott, 2008). Also a firm's success in combining the new knowledge with the one existing inside it, and then applying the new knowledge to create an innovative value, depends on both prior related knowledge and the activities aimed at gathering knowledge, and embedding it within a firm's routines (Cohen \& Levinthal, 1990; Child et al., 2005; Nag \& Gioia, 2012).

While examining the issues of intra- and inter-firm learning in the reference literature, we can observe the interchangeable use of organizational learning and absorptive capacity concepts. We assume that it results from the conceptual affinity of both concepts. Existing literature examining the relationships between absorptive capacity and organizational learning 
concepts presents some divergent views. Several authors perceive absorptive capacity as an antecedent of organizational learning (Mowery, Oxley \& Silverman, 1996; Szulanski 1996; Reagans \& McEvily 2000; Meeus, Oerlemans \& Hage 2001; Oliver 2001; Kim \& Lee, 2002). As highlighted by these authors, firms with a high level of absorptive capacity are likely to recognize and utilize new knowledge from outside a company to strengthen their innovativeness and competitiveness. Following this approach, organizations must have the capacity to absorb inputs to be able to generate outputs. For example Szulanski (1996), who conducted research on knowledge transfers in 122 companies, found that lack of absorptive capacity was a main barrier to internal knowledge transfer within a firm. Such correctness is related to the fact that absorptive capacity results from a long-lasting process of knowledge accumulation (Szulanski, 1996; Tsai, 2001). According to another literature stream, absorptive capacity is viewed as an outcome of organizational learning (Liao, Fei \& Chen, 2007; Schilling, 2002). The studies conducted by Liao et al. (2007), as well as by Schilling (2002), prove that knowledge sharing within a firm increases its stock of prior knowledge, which in fact means building a firm's absorptive capacity. Moreover, following the third approach, absorptive capacity and organizational learning are perceived as having a recursive relationship (Autio, Sapienza \& Almeida, 2000; Barkema \& Vermeulen, 1998; Cohen \& Levinthal, 1990; Lane \& Lubatkin, 1998; Tsai 2001). This approach suggests that a firm's absorptive capacity enables a company to learn from external sources (such as inter-firm R\&D cooperation) and next this learning is invested and exploited by internal R\&D activities, which build a firm's absorptive capacity. This in turn results in a firm's greater $R \& D$ cooperation with external sources and thus further learning.

Referring to the model of absorptive capacity proposed by Zahra and George (2002) and the model of organizational learning by Crossan et al. (1999), in their framework Sun and Anderson (2010) propose the following involvement of organizational learning processes into the components of absorptive capacity. Knowledge acquisition is argued to be a learning capability including intuition and interpretation processes at individual and group levels of learning. Knowledge assimilation is perceived as a group learning activity involving interpretation processes. Knowledge transformation is related to integration processes that are observed at group and organizational levels. And finally, according to Anderson and Sun, knowledge exploitation refers to the process of institutionalization at the organizational level (Sun \& Anderson, 2010, pp. 141-146). In other words, Sun and Anderson suggest that absorptive capacity should be perceived as a concrete example of organizational learning that concerns a firm's relationship with new external knowledge (Sun \& Anderson, 2010, p. 130). 
Inspired by the study of Sun and Anderson (2010), Lis (2016) investigates the relationships between the concepts of organizational learning and lessons learned, and observes a similar affinity between them. In his study, Lis (2016) compares and contrasts the Crossan et al. (1999) model of organizational learning with the Milton (2010) lessons learned lifecycle (modifying it a little through splitting a lesson identification stage into two phases i.e. observation collection and analysis). According to the model, observation collection is an equivalent of the intuition process. In the stage of gathering observations, referring to their experience and expertise, organization members identify the gaps between the reality and expected (model) outcomes, notify best practices i.e. the behaviors not institutionalized yet which proved their effectiveness in solving organizational problems or they provide recommendations for organizational improvements. Identified observations are submitted to the lessons learned systems (cf. Milton, 2010; Jabłoński \& Lis, 2012, p. 178). The externalization of observations made by organization members which is an equivalent of idea extraction in the employee suggestion process (cf. van Dijk \& van den Ende, 2002, p. 389) matches to the idea of "the preconscious recognition of the patterns and/or possibilities in a personal stream of experience" i.e. intuition in the model by Crossan et al. (1999, p. 525). Analysis of an observation submitted refers to the process of interpretation. In the analysis stage, organization members make attempts to discover the root causes of identified problems, their antecedents and related aspects, and develop recommendations for further actions. This stage of the lessons learned process resembles idea landing in the model of the employee suggestion process (cf. van Dijk \& van den Ende, 2002, p. 389) and shares affinity with interpreting in the $4 \mathrm{l}$ framework of organizational learning which is defined as "the explaining, through words and/or actions, of an insight or idea to one's self and to others" (Crossan et al., 1999, p. 525). Planning and implementation of remedial actions correspond to the process of integration and partially to institutionalization in the 41 framework. Planning and implementation of remedial actions establish the bridge between knowledge management and change management processes and they occur at the group and organizational levels. Their gist manifests in "the process of developing shared understanding among individuals and of taking coordinated action through mutual adjustment" (integration) and "the process of ensuring that routinized actions occur" (institutionalization) (Crossan et al., 1999, p. 525). Finally, dissemination of lessons and best practices may be considered as the embodiment of the institutionalization process in the $4 \mathrm{l}$ framework, as it is used as one of the tools for sharing institutionalized knowledge within an organization. The stages of planning and implementing remedial actions, as well as lessons dissemination, seem to share affinity with the phase of idea 
follow-up in the model of the employee suggestion process (cf. van Dijk \& van den Ende, 2002, p. 389). Summing up, lessons learned can be considered as a particular example of intra-organizational learning processes based on experiential knowledge of organization members. It should be highlighted that the aforementioned assumptions concerning the affinity of the model of the lessons learned process and the $4 \mathrm{I}$ framework of organizational learning, seem to be logical in the light of discussed theories but they are relatively fresh ideas which have not been tested empirically. Therefore, making the first attempt to their empirical validation will be an additional contribution of the paper.

Taking into account the aforementioned studies showing the affinities between absorptive capacity and organizational learning as well as lessons learned and organizational learning (cf. Table 1), an attempt can be made to combine them and analyze the relationships between them.

Table 1. The comparative analysis of the processes of organizational learning, absorptive capacity and lessons learned

\begin{tabular}{|c|c|c|c|c|}
\hline Levels of learning & Individual & $\begin{array}{l}\text { Individual } \\
\text { and group }\end{array}$ & $\begin{array}{l}\text { Group and } \\
\text { organizational }\end{array}$ & Organizational \\
\hline $\begin{array}{l}\text { Organizational } \\
\text { learning }\end{array}$ & intuiting & interpreting & integrating & institutionalizing \\
\hline $\begin{array}{l}\text { Absorptive } \\
\text { capacity }\end{array}$ & acquisition & assimilation & transformation & exploitation \\
\hline \multirow[t]{2}{*}{ Lessons learned } & \multicolumn{2}{|c|}{ lessons identification } & $\begin{array}{l}\text { planning and } \\
\text { implementation }\end{array}$ & dissemination \\
\hline & $\begin{array}{l}\text { observation } \\
\text { collection }\end{array}$ & analysis & $\begin{array}{l}\text { of remedial } \\
\text { actions }\end{array}$ & \\
\hline
\end{tabular}

Source: Authors' work based on Crossan et al. (1999), Zahra and George (2002), Milton (2010) and Lis (2016).

Concluding, absorptive capacity and organizational learning concepts share several theoretical similarities and both are said to enable the strategic renewal of a firm. The dynamic capability of absorptive capacity is perceived as a building block, creating new core competences of a company that undergoes a strategic change. Also, organizational learning provides the new organizational competences needed for strategic renewal. Therefore, we follow the view of Sun and Anderson (2010) who argue that absorptive capacity should be perceived as a specific type of organizational learning that refers to a firm's relationships with external knowledge, and the view of Lis (2016) confirming the affinity between organizational learning and lessons learned processes. The empirical part of the paper is an attempt to exemplify the synergy of absorptive capacity and learning lessons through employee suggestions, upon the case study of the firm Frauenthal Automotive Torun. 


\section{RESERCH METHOD}

\section{Method of the study}

The single case study analysis is chosen as the research approach to achieve the aim of the study i.e. to explore the relationships between the processes of absorptive capacity (inter-firm learning) and learning lessons through employee suggestions (intra-firm learning) and identify potential synergies between them. The usefulness of the qualitative approach to analyze the issues related to absorptive capacity is highlighted by Duchek (2013) who claims that "a practice-based approach and the use of qualitative methods, such as ethnographies and narratives, are the most appropriate methods of identifying the routines or practices that build absorptive capacity" Duchek $(2013$, p. 325$)$. The review of literature confirms that the case method is applicable to absorptive capacity studies and finds its proponents (cf. Kim, 1998; Van den Bosch, Volberda \& De Boer, 1999; Easterby-Smith, Graça, Antonacopoulou \& Ferdinand, 2008; Noblet, Simon \& Parent, 2011; Duchek, 2013; Lis \& Sudolska, 2015). Similarly, the case study methodology is used in research of organizational learning processes (cf. Crossan \& Berdrow, 2003), lessons learned capabilities (cf. Burley \& Pandit, 2008; Foley, Griffin \& McCartney, 2011; Jabłoński \& Lis, 2012) and employee suggestion systems (cf. van Dijk and van den Ende, 2002).

The research process followed the pattern recommended in methodology literature (cf. Yin, 2010; Strumińska-Kutra \& Koładkiewicz, 2012, cf. Patton \& Appelbaum, 2003; Stake, 2010) and included: (1) defining study questions; (2) selecting the unit of analysis and the sample within the studied case; (3) planning and collecting data; (4) analyzing data; and (5) writing a case study analysis. As the research is driven by exploratory philosophy, instead of formulating theses or hypotheses, two study questions were proposed:

- How do organizations apply external knowledge to support intraorganizational learning processes?

- How should the employee suggestion system be organized to increase (or build) absorptive capacity?

Inter-firm and intra-firm learning processes observed in Frauenthal Automotive Toruń (FTO) were chosen as the unit of analysis. Taking into account the macro-level perspective FTO, being a Polish subsidiary of an Austrian corporation, should be considered as a case operating in the pre-frontier or close to frontier-sharing stage context. In such a context it becomes more and more challenging to acquire new, external knowledge due to its increasing complexity and difficulties in getting access to valuable knowledge off the shelf. Therefore, emphasis is given to the development 
of new knowledge through cooperative strategies such as joint ventures or alliances (cf. Narula, 2003).

In earlier studies, it was proved that FTO is a company representing a high level of absorptive capacity. Lis and Sudolska (2015) measured the level of potential and realized absorptive capacity in FTO with the use of scales proposed by Jansen, Van Den Bosch and Volberda (2005). Their findings indicate that FTO absorptive capacity is very close to the benchmark made by Jansen et al. (2005) and even exceeds it in the component of knowledge acquisition. Although u-bolts for trucks manufactured by FTO are not stateof-the-art products and there is little room for product innovations, the company operates in a highly competitive industry and makes every effort to defend its number one position in the European market and to diversify in related businesses. Therefore, FTO pays a lot of attention to learning processes both in the inter-firm and intra-firm context which are oriented to process innovations, in order to seek an increase in efficiency and to strengthen the firm's competitive advantage. Moreover, what is worth mentioning is that the management team at FTO is open to participate in research projects, which allows us to smoothly conduct the study process. Semi-structured interviews and the analysis of company documentation were applied for collecting data. Five managers at FTO contributed to the study as interviewees. The respondents were selected due to their knowledge and understanding of organizational learning processes. The primary parameters of sampling are presented in Table 2.

Table 2. Primary parameters of applied sampling

\begin{tabular}{ll}
\hline Characteristics of the sample & Informants \\
\hline $\begin{array}{l}\text { The company operates in the automotive } \\
\text { components industry }\end{array}$ & Managing Director (MD) \\
$\begin{array}{l}\text { The leader in the European market of u-bolts } \\
\text { for trucks }\end{array}$ & Human Resources Manager (HRM) \\
$\begin{array}{l}\text { Orientation to defend its market position and } \\
\text { diversify in related businesses }\end{array}$ & Production Manager (PM) \\
$\begin{array}{l}\text { Strong orientation to organizational learning } \\
\text { including both inter-firm and intra-firm }\end{array}$ & Quality Manager (QM) \\
$\begin{array}{l}\text { learning } \\
\text { Representing a high level of absorptive } \\
\text { capacity confirmed by earlier research }\end{array}$ & Continuous Improvement Leader (CIL) \\
\hline
\end{tabular}

The interviews related to inter-firm and intra-firm learning processes and relationships between them. Discussions focused on processes enumerated in the model presented in Table 1. First of all, it was our idea to externalize knowledge and opinions of the respondents focusing on structural aspects organized around the issues of applying external knowledge to support intraorganizational learning processes and organizing the employee suggestion 
system to increase the company absorptive capacity. Structural dimensions were based on the phases of absorptive capacity and lessons learned processes and included the following components: (1) absorptive capacity: acquisition, assimilation, transformation and exploitation; (2) lessons learned: lessons (employee suggestions) identification, analysis, remedial actions implementation and lessons (employee suggestions) dissemination. We provided the respondents with short definitions for each dimension and we explained key indicators. Secondly, we enabled the interviewees to contribute to the study with the issues related to the subject which emerged during interviews. Each interview lasted on average about 90 minutes. All of them were conducted at the company's site in Toruń, Poland. In accordance with earlier arrangements with the management of the company, paper and pencil interviews (PAPI) were not recorded. The time perspective of interviews was concentrated on current operations of the company. However, some examples from the history were elicited having as reference points the takeover of the company by the Austrian corporation Frauenthal and a shift from a family business to a corporate model (2007) and the beginning of the Lean Management program implementation (2010). Moreover, the documentation of the company related to the employee suggestion system was analyzed. The analysis included: the procedure of staffing employee suggestions, compensation regulations related to employee suggestions, 'Trust Curve' charts presenting the number of ideas proposed within the employee suggestion system each month and comparing it with the number of improvements introduced out of these suggestions. While analyzing collected data, we applied a thematic content analysis method based on the units of meanings such as: words, events or practices. We used the stages of the absorptive capacity and lessons learned processes identified in Table 1 to categorize collected data. Moreover, we made an attempt to assess the influence the processes of absorptive capacity and learning lessons through employee suggestions have on each other. Initially, it was our intent to use the point assessment scale ranging from 1 to 10 . However, during interviews we realized difficulties in applying the point assessment. Therefore, we followed the suggestions of our respondents and changed to the descriptive assessment scale including three levels measuring the intensity of mutual influence between the processes of absorptive capacity on learning lessons through employee suggestions i.e. low, medium and high influence (cf. Tables 3 and 4). Certainly, we are aware of the limitations related to such a simplification which should be eliminated in prospective studies.

In order to ensure the quality of the research we judged our case study against the criteria of construct validity, external validity and reliability. Applying the testing procedure we followed tactics recommended by Yin 
(2010, pp. 201-206). Construct validity was assured by the use of a variety of data sources and a review of the draft of the case study report by key informants. As regards external validity we are aware of the limitations of a single case study method to develop generalization. However, relying on analytical generalization we made attempts to compare and contrast our findings from FTO against the theory and concepts of other researchers in the field. We used a case study protocol and a case study database to ensure that the research process was properly documented to provide the required level of reliability. As our research represents an exploratory approach, we followed the suggestion to exclude the test of internal validity, which according to Yin (2010), should be applied for explanatory or casual case studies but not for exploratory cases.

The structure of the case study analysis includes: the presentation of the study context, the analysis of the inter-firm and intra-firm learning processes identified in FTO, and the two sided analysis and discussion of relationships and possible synergies between inter-firm learning (with the focus on the absorptive capacity process) and intra-firm learning (focused on but not limited to learning lessons through the company employee suggestion system).

\section{Context of the study}

Frauenthal Automotive Torun (FTO) is a Polish subsidiary of the Austrian corporation Frauenthal Automotive Components. FTO is a metal processing company operating in the automotive components industry. The company is number one in the European market for u-bolts (metal u-shaped elements with screw threads on both sides used to fix a chassis and a body of heavy trucks) and number two globally in this niche industry. Main customers of FTO are: Volvo (32\% of sales in 2013), Scania (27\%), BPW (21\%) and Renault Trucks (15\%).

FTO was established in 1993 by a Swedish entrepreneur under the name Pol-Necks. Since 2000 , the company has been producing u-bolts, mastering in cold bending technology and (since 2003) in hot bending technology. In 2004, the standard ISO/TS 16949:2002 was implemented and production reached a level of 1 million of u-bolts. In 2005, the company introduced the in-house Dacromet painting technology enabling it to stand-out from its competitors. In 2007, the company was taken over by the Austrian corporation Frauenthal Automotive Components, the business portfolio was extended to include pins and screws, and ISO 14000:2004 and OHSAS 18001:2007 were implemented. In spite of problems in the automotive industry as a result of the world economic crisis (2008), the company showed high resilience and 
quickly recovered, reaching a production level of 2 million u-bolts in 2010 . Moreover, the change in ownership resulted in investment in new machinery and production process optimization (Historia firmy, nd), and in 2011 sales rocketed to 2.8 million units. In 2012, the company changed its name to Frauenthal Automotive Toruń and since 2016 has also been a supplier to Volkswagen.

FTO is a medium-size enterprise with ca. 150 people. The key components of the FTO organizational structure include: Production Department, Development Department, Finance Department, Sales Department, Quality Manager Office, and HR Business Partner Office.

\section{ANALYSIS}

\section{Inter-firm learning process}

Frauenthal Automotive Toruń actively searches for knowledge in its environment and is very open to inter-firm learning. The company makes attempts to learn from other companies within the Frauenthal group, its customers, suppliers and business partners. FTO shares lessons and best practices within the framework of the Frauenthal business family. As noticed by the HR Manager, for instance "[t]he approach of searching for internal and external knowledge has been applied while planning the implementation of the SAP system. We visited other plants in the Frauenthal Group which implemented SAP one or two years ago and have collected best practices as well as we have learned from their mistakes. On top of that we added to it our internal knowledge and expectations on how business systems work or should work." Learning from customers is achieved through analyzing their requirements and complaints. FTO pays a lot of attention to understanding the detailed specification of requirements of its customers and translating them into intra-organizational procedures and routines. Moreover, the company has established formal procedures to assimilate, transform, and exploit knowledge acquired from complaints submitted by customers. Customer requirements, reviews and feedback are used to optimize FTO internal processes. As highlighted in the interviews with the Managing Director: "Claims create an opportunity to learn and change things for the future. The team dealing with claims look for short- and long-term solutions". In order to better understand the needs of customers and their processes, FTO employees visit customer plants. The suppliers of machines and equipment are invited to share their expertise with FTO employees under the umbrella of "supplier days". FTO has established close learning relationships with the stakeholders in its local environment e.g. universities and technical 
secondary schools. Business relations and visits to other companies play an important role in combining inter-firm and intra-firm learning. What is interesting is that the company is open for inter-firm learning through site visits even with some of its competitors. For instance, the FTO Managing Director during his visit to a competitor in Brazil (which is a potential partner for a joint venture), was inspired by the competitor's production system. As the result, he came up with an idea concerning the reduction of steel losses. The idea requires some changes (mostly technical) within the production system. Thus, the managers and employees of the production department have been tasked with proposing changes in order to reduce FTO steel losses. Another field of applying external knowledge to strengthen intraorganizational learning is sponsoring employees' studies at universities. When an employee is appraised highly by a supervisor and is willing to study, FTO will fund such education. In this case, an employee usually knows what areas of knowledge he/she lacks in particular and through attending university courses, he/she gets such knowledge. What is of significant importance is that an experienced employee has his/her own reflections concerning work, frequently resulting in some suggestions. Employee consciousness about the possible improvements in the company enables new knowledge acquisition, assimilation, transformation and finally exploitation. Also, employees who study are obliged to perform traineeships in other companies. This obligation results in sharing the experience of the studying employee with the workers of other companies and thus acquiring new knowledge. Then, this new knowledge is assimilated, transformed and exploited by FTO.

What is significant while considering combining inter-firm and intra-firm learning, is that FTO has developed several practices used for processing, assimilating and transforming new external knowledge in order to be able to exploit it properly. Such techniques involve: writing memos after business meetings and visits, disseminating new knowledge among other employees during working meetings, discussing the possibility of new knowledge exploitation in FTO. What is of particular note is that FTO employees expect their supervisors and colleagues to share the knowledge that they acquired during meetings with business partners. Thus, in order to facilitate knowledge processing and knowledge sharing among employees, FTO has established electronic knowledge repositories (Frauenthalpedia, Management Planet).

The interviews with FTO managers reveal interesting examples of positive outcomes of such a cooperation oriented to inter-firm learning. As observed by the Managing Director: "We have had a development program with one of the tools' suppliers (thread rolls). The effect of the collaboration is a design of new tools not available in supplier's catalogues. Before the improvements, one set of thread rolling tools was used to produce around 
400 pieces - now it is 620 to 780 pieces per one set of tools". Another case is provided by the Continuous Improvement Leader who states: "We had a one-year-development-program involving three partners: machine supplier, tools' supplier and ourselves. There were minor changes implemented into the processes (FTO), the set-up of the machine (machine supplier) and the design of the tool (tools' supplier), which doubled the life-time of tools from 40,000 to 80,000 pieces per tool".

\section{Intra-firm learning process}

As regards intra-firm learning by FTO employees, the company has two approaches: managers/engineers proposals and the employee suggestions system. First of all, there are some employees (e.g. managers or design engineers) whose job descriptions include the responsibility for intra-firm learning aimed at generating improvements and innovations. When approved, the ideas submitted by managers and engineers are usually implemented in the company as independent projects due to the fact that they are usually non-standard changes, they are mid- or long-term ventures and they need allocated resources. Managers/engineers proposals are a part of the white collar employee duties and they are not extra remunerated or awarded. All other members (mainly blue collars) are encouraged to contribute to organizational learning processes through the employee suggestion system. Submissions to the formal employee suggestion system are made on a voluntary basis and they are recognized and rewarded in accordance with compensation regulations included into the company remuneration policy.

Theemployee suggestion system is closely connected with implementation of the Lean Management philosophy which started in 2010. First of all, the $5 S$ technique was introduced on the shop-floor. Then, the following Lean Management techniques and tools were added: Quality Control, SMED, Total Productive Maintenance, Value Stream Mapping, Gemba Walk and Poka Yoke. Certainly, the employee suggestion system as a prerequisite of the continuous improvement approach was founded and developed. FTO has formal procedures for the conduct of the suggestion process. Employees are invited to submit their suggestions for improvement to the committee responsible for analyzing them and validating the value of submissions. The company has introduced a suggestion form which is completed by a submitting employee. The main areas of interest of the employee suggestion program encompass: occupational health and safety (OH\&S), quality, performance, ergonomics and organization of work. Submitted observations should define problems or possible areas for improvement and provide recommended solutions. If an employee submitting a suggestion is not able to analyze root causes of the 
problem or develop recommendations for remedial actions, the committee appoints an expert who validates the value of the suggestion and elaborates on it in order to provide a solution. When submissions are positively assessed by the committee they are forwarded to the Managing Director for final approval. Depending on available resources and the CEO's decision, the company either implements remedial actions recommended in suggestions, maintains them in on hold, or refrains from any action. When a suggestion is approved for implementation by the Managing Director the remedial action body is assigned to it. Such a body is responsible for planning and implementing recommended changes. The employee suggestion procedure in FTO is consistent with the theoretical models proposed by Neagoe and Marascu Klein (2010) or Van Dijk and van den Ende (2002).

Employee suggestion processes are staffed and managed by the Continuous Improvement Leader and members of the committee including the representatives of the Departments of Production, Financial Control, Quality, OH\&S and Sales. Managers, especially in the Production Department, are expected to provide employees with information on areas of particular importance, which are the guidelines as to where suggestions should be searched for. Shift leaders are also considered to play an important role in encouraging employees to submit suggestions and share knowledge between the teams. Employee contribution to the suggestion system is motivated with financial rewards. Showing a willingness to identify improvements and share knowledge with others are important criteria for recognizing the best workers of the month. Moreover, contribution to company improvement and innovation is an official requirement to be promoted to level 3 in the 4-grade hierarchy of blue collar positions. Transparency is an important characteristic of the FTO employee suggestion system. The company officially informs about submitted suggestions, contributors and the status of issue resolutions. The management shows a high level of concern about filling the gap between the number of submissions and resolved issues.

To encourage employees to come up with ideas for improvements, FTO has introduced a solution called 'Trust Curve'. The idea of 'Trust Curve' is measuring the number of ideas proposed within the employee suggestion system each month and comparing it with the number of improvements introduced out of these suggestions. What is important is that FTO management pays a lot of attention to keeping the gap between these two numbers as small as possible in order to show employees that the company appreciates their ideas, which leads to an increase in employee trust towards the company and managers, and employee commitment. 


\section{Applying external knowledge in the intra-firm learning}

The first, and a very prominent, manifestation of using external knowledge for intra-organizational learning in Frauenthal Automotive Torun is the company suggestion system. The idea of the employee suggestion system was recognized and imported from an external business partner by the Production Manager. Similarly, the reorganization and upgrade of the employee suggestion procedures were catalyzed by experiential knowledge acquired from an external company by the Continuous Improvement Leader.

As regards the possibility to apply external knowledge, due to the firm absorptive capacity in the processes of employee suggestions and managers/ engineers proposals implementation, it varies depending on the phases of the processes of learning lessons (cf. Table 3).

Table 3. The influence of applying external knowledge on learning lessons through employee suggestions

\begin{tabular}{|c|c|c|c|c|c|}
\hline \multirow{2}{*}{\multicolumn{2}{|c|}{$\begin{array}{l}\text { Lessons learned from em- } \\
\text { ployee suggestions }\end{array}$}} & \multicolumn{2}{|c|}{ Lesson identification } & \multirow{2}{*}{$\begin{array}{l}\text { Implementa- } \\
\text { tion of reme- } \\
\text { dial actions }\end{array}$} & \multirow[b]{2}{*}{ Dissemination } \\
\hline & & $\begin{array}{l}\text { Observation } \\
\text { generation }\end{array}$ & Analysis & & \\
\hline \multirow{2}{*}{$\begin{array}{l}\text { Absorptive } \\
\text { capacity } \\
\rightarrow\end{array}$} & $\begin{array}{l}\text { Managers/ } \\
\text { engineers pro- } \\
\text { posals (white } \\
\text { collars) }\end{array}$ & high & medium/high & medium/high & low \\
\hline & $\begin{array}{l}\text { Employee sug- } \\
\text { gestion system I } \\
\text { (blue collars) }\end{array}$ & low & low/medium & low/medium & low \\
\hline
\end{tabular}

\section{Observations/suggestions collection}

Generation of employee suggestions may be triggered by acquiring external knowledge by employees who confront it with the situation in the company. Identification of the gap may be a direct force motivating employees to submit an observation or a suggestion. An interesting example is the heating of steel rods before processing them in a hardening machine. The idea was observed by one of company engineers in other metal-processing companies and adapted to the FTO technological process. As highlighted by the respondents, the influence of external knowledge on the company intraorganizational processes is much more observable in the case of proposals submitted by white collars (managers and engineers), who usually have more opportunities to cooperate with external partners. During the interview, the Managing Director emphasized the paramount importance of such inspirations: "Sometimes it is enough to have one inspiring discussion for the 
idea to be born. As soon as we see benefits from implementing the idea we consistently aim to achieve that. Such an example was a meeting with the CEO of Gnotec, one of the companies in the Frauenthal Group. He explained to us how their MRP system supports their processes of implementing new products. A year after we have our APQP process planned and monitored in our MRP system".

\section{Observations/suggestions analysis}

While employee suggestion is staffed, there may be a requirement to search for external knowledge and expertise in order to elaborate on the submitted issue and propose the solutions to observed problems. For instance, while proceeding with one suggestion concerning saving electrical energy, FTO invited a third party to audit the lighting in the factory and build-up a body of knowledge necessary to make decisions on remedial actions. Another example was provided by the HR Manager who observed: "When we face a problem we do not fully understand that we are actively looking for knowledge - I remember once an issue with electrostatics on the painting line. We asked a fourth-year-student of physics to deal with the topic during his internship. He collected data from our painting line and processed them with the help of mathematical algorithms. His results helped us to change the process parameters and at the end he conducted some training for our employees". Moreover, as highlighted by the respondents, while analyzing submitted problems or assessing submitted proposals, FTO searches for knowledge among partner companies in the Frauenthal Group. As proposals submitted by managers and engineers are usually more complex and multidimensional than blue collars' suggestions, this category of observations and lessons is more prone for analysis by engaging the knowledge of external actors.

\section{Remedial actions implementation}

Similarly, in the same way the knowledge of external parties may be absorbed in the phase of remedial actions implementation. The modernization and upgrade of the shot blasting machine was mentioned as an example of the remedial action driven by employee suggestions which required the company to combine its intra-organizational knowledge of processes with external technological expertise. However, as observed by the informants, sometimes FTO managers seem to be rather reluctant to involve external partners to implement improvement triggered by employee suggestions. On the one hand, FTO is the leader within its industry and the company shows technical advancement in comparison with competitors which may result in the emergence of the "not invented here syndrome". On the other hand 
managers, who are expected to strictly control budgets, prefer implementing improvements with internal resources even if such solutions result in postponing remedial actions.

\section{Lessons dissemination}

As regards dissemination of lessons and best practices in the company, the influence of external knowledge is hardly observable. So, both in the case of managers/engineers proposals and blue collars suggestions the impact was assessed as low.

\section{Applying intra-firm learning to strengthen company absorptive capacity}

The respondents highly value the role of FTO intra-firm learning processes for the company absorptive capacity. According to their subjective opinions, this influence may be assessed as medium or high. The detailed insights concerning each component of absorptive capacity are pointed out in Table 4.

Table 4. The influence of learning lessons through employee suggestions on absorptive capacity

\begin{tabular}{lllll}
\hline $\begin{array}{l}\text { Absorptive } \\
\text { capacity }\end{array}$ & Acquisition & Assimilation & Transformation & Exploitation \\
\hline $\begin{array}{l}\text { Lessons learned } \\
\text { from employee }\end{array}$ & high & medium/high & medium & medium \\
$\begin{array}{l}\text { suggestions/ } \\
\text { proposals }\end{array}$ & & & \\
$\rightarrow$ & & & \\
\hline
\end{tabular}

The employee participation in the suggestion system enables FTO to identify the most effective learners among blue collars and engage them in scanning for external knowledge. As already mentioned, activeness in providing suggestions for improvements is an important criterion to nominate the best workers of the month. Such employees are included into the FTO delegations visiting sites of the company's business partners (e.g. production lines of leading world truck manufacturers). On the one hand it is a form of reward for employees, but on the other one FTO uses their learning capabilities to recognize and acquire external knowledge. It is also of high importance that engagement in intra-firm learning processes strengthens employee awareness of knowledge gaps, their capability to recognize valuable knowledge in the environment and bring this knowledge to the company, as well as developing employee openness to new ideas and solutions.

Strengthening the existing body of knowledge within the company is another important but indirect aspect of the influence of employee 
suggestion systems on its absorptive capacity. As already mentioned, FTO has a strong orientation to improve and develop its capabilities on the foundation of intra-organizational knowledge. Therefore, while the company is working on a problem, first of all the intra-organizational processes are triggered. Then, external knowledge is searched, recognized, acquired and confronted with already existing knowledge resources. As a matter of fact, the company is making efforts to implement the philosophy of the learning organization concept. It is manifested in the declaration made in his interview by the Continuous Improvement Leader: "We [FTO] are a learning organization and we willingly use the knowledge of third parties. We want to learn from others".

For instance, FTO has a specific idea (procedure) that has been internally created and implemented and is called 'Tea after Tea'. When FTO employees, both white and blue collars, are delegated for any training course, they are obliged to prepare for it. It means that first they have to learn a bit about the issues that the training course includes. Thus, they can learn from books, but also from sharing knowledge and expertise with other employees. Such preparation is verified by a qualified employee (supervisor). Moreover, after the course they are obliged to solve a kind of problem related to the field of a training course. Again, this is verified by a qualified supervisor. Such an approach forces employees to deepen their individual knowledge and thus to be more active in the system of employee suggestions. On the other hand, deepening individual knowledge before training enables better and quicker acquisition, assimilation and transformation of new knowledge, finally leading to its exploitation.

Moreover, as FTO is a learning-oriented company, the engineers employed in the firm deliver "lessons of physics" to blue collars. The idea is called GILO and its purpose is to deepen workers' basic knowledge of physics and make them more conscious of physics' phenomena related to their job tasks. Thus, they become more able to come up with new ideas and improvements. Deepening employees' knowledge is done internally firstly, but if it is needed, experts from universities are invited to provide more knowledge on specific issues. Thanks to such activities, FTO combines intra-organizational learning with external knowledge acquired from the experts. 


\section{DISCUSSION}

The results presented in the paper are aligned with the evidence found in the relevant literature which includes a number of works focusing on the enterprises' abilities to combine the processes of intra-firm learning with recognizing and acquiring, then assimilating and transforming as well as exploiting new external knowledge in order to generate new valuable solutions, technologies, products etc. Several authors highlight that the ability to recognize, acquire, assimilate, transform and exploit the desired knowledge, strongly depends on the enterprises prior knowledge generated, among others, through intra-firm learning (e.g. Cohen \& Levinthal, 1990; Schilling, 2002; Child at al. 2005; Liao et al., 2007, Trott, 2008, Nag \& Gioia, 2012). On the other hand, there are researchers who claim that absorptive capacity should be perceived as an antecedent of intra-firm learning (e.g. Mowery et al., 1996; Szulanski, 1996; Reagans \& McEvily, 2000; Meeus et al., 2001; Oliver, 2001; Kim \& Lee, 2002). Combining our research findings with those of the aforementioned authors it proves that developing both intraand inter-firm learning through strengthening a firm's absorptive capacity leads to synergic outcomes. Moreover, the paper contributes to the literature and research on organizational learning processes as it is an attempt to highlight the affinity of the model of the lessons learned process and the $4 \mathrm{I}$ framework of organizational learning proposed by Crossan et al. (1999). Such an approach concerning theory as well as empirical validation is relatively new. However, the empirical contribution of the paper particularly refers to exploring how the techniques and best practices associated with FTO's ability to combine intra- and inter-firm learning, contribute to the company's knowledge and its outcomes.

From the FTO case we have learnt that several techniques and practices concerned with acquiring new knowledge (such as studying customer's requirements and complaints, other companies visits, external training and new knowledge sharing with other employees, university courses etc.) may have a high or at least a moderate influence on internal learning through the employee suggestion system. Workers' activity in the field of generating improvement-oriented suggestions is frequently triggered by some external knowledge acquired by employees, in particular those of managerial positions (e.g. from visiting business partners or trade fairs). External knowledge may be used to support the processes of analysis and remedial actions implementation, and to a lesser extent, lessons dissemination. Therefore, the proposal is set that absorptive capacity reveals itself on every stage of the organizational learning process (i.e. employee suggestion or lessons learned 
process in this particular case) but with the use of different procedures and schemes $^{5}$.

While considering the influence of learning through employee suggestions on inter-organizational learning (throughout absorptive capacity development), our research findings allow us to assume that such an influence might be stronger in the case of potential absorptive capacity (acquisition and assimilation) at FTO. As potential absorptive capacity includes acquisition and assimilation of new knowledge, it seems important to stress that according to Sun and Anderson (2010), "assimilation is influenced by dialogue, diversity of team member experience, and a supportive environment for innovation, each of which makes it more likely for novel and frame-breaking insights to be verbalized and articulated" (Sun \& Anderson, 2010, p. 144). Following this statement, we assume that implementing the employee suggestions program in FTO is an important activity that helps to enhance the absorptive capacity of the firm. Sun and Anderson emphasize the significance of dialogue within a company. This in fact refers to communication through which employees become familiar with one another and develop mutual trust. In turn they become more eager to share sensitive information that can lead to any novelty (Sun \& Anderson, 2010). Our findings prove that sharing knowledge acquired by employees from external sources, such as a customer's requirements and complaints, other companies' visits or external training, is a common practice in FTO (e.g. Tea after Tea practice) that frequently brings new solutions to the firm's operations and outcomes.

With reference to realized absorptive capacity we found less explicit examples. However, we would like to emphasize that a good practice concerning the employee suggestion system in FTO, that is rewarding workers for coming up with improvement ideas, is a way of influencing realized absorptive capacity, particularly at the exploitation stage. Again following Sun and Anderson (2010), we stress that "exploitation is influenced by leadership activities involving reward and recognition mechanisms and the effective deployment of organizational resources by ensuring a timely and effective restructuring of organizational memory" (Sun \& Anderson, 2010, p. 145) Exploitation refers to enterprise capability to incorporate the newly acquired knowledge and transform it into a firm's operations so it can be continuously refined and exploited (Zahra \& George, 2002). In our opinion it is of significant importance that FTO management has introduced a very clear reward system related to employee suggestions that, as suggested by Sun and Anderson, ensures effective restructuring of FTO's organizational memory. Moreover, following Jansen et al. (2005) who claim that formalizing and documenting

5 The authors are grateful to the anonymous reviewer for their suggestion leading us to such a statement.

6 The authors are grateful to the anonymous reviewer for this suggestion. 
any rules, procedures or processes in an organization positively influences the learning capability of exploitation, we argue that several practices related to the intra-firm learning of FTO described in the paper play an important role in strengthening a firm's realized absorptive capacity.

Summing up, we argue that the identified techniques, practices and procedures used by FTO to combine intra- and inter-firm learning in order to make progress and generate valuable novelty confirm applicability as well as high utility of such an approach. We follow Cohen and Levinthal who claim that "[a]bsorptive capacity refers not only to the acquisition or assimilation of information by an organization but also by an organization's ability to exploit it. Therefore, an organization's absorptive capacity does not simply depend on the organization's direct interface with the external environment - it also depends on transfers of knowledge across and within subunits" (Cohen and Levinthal, 1990, p. 131). An interesting case study illustrating the role of prior related knowledge and intra-firm learning processes for the effectiveness of inter-firm knowledge transfer is provided by Daghfous (2004). He studied a project related to technology transfer between a university research center and a plant of a multinational company operating in the microelectronic components industry. Referring to Daghfous (2004), Noblet et al. (2011, p. 368) observe that "[ $f]$ or an organization to increase its absorptive capacity, it needs to boost its ability to transform and implement external knowledge within the company so as to enhance its core competencies". The implementation of an employee suggestion system can be perceived as a firm's way to "boost the ability to transform and implement internal knowledge" ${ }^{\prime \prime}$. The analysis of the FTO case study confirms this observation as, in order to come up with the new ideas for improvements, the employees have to learn (both on an individual and group level), study and analyze the existing processes and reflect on it to identify new potential solutions. At the same time employee participation in the suggestion system allows FTO to identify the most effective learners and engage them in searching for external knowledge as being rewarded they have an opportunity to visit sites of the company's business partners. Such an approach enables FTO, utilizing best employees' learning capabilities, to recognize and acquire external knowledge valuable for the firm.

The procedures related to sharing knowledge in FTO described in the paper prove the existence of knowledge transfer within the firm that constitutes the base for implementing more effective/innovative ways of performing and enhancing FTO core competences. Drawing on literature, we stress that increased learning in a particular field increases the firm's knowledge base in this field which further enhances its absorptive capacity and facilitates more learning in this domain (Barkema \& Vermeulen, 1998; Autio et al., 2000; Lane

7 The authors are grateful to the anonymous reviewer for this suggestion. 
et al., 2006). Developing its body of knowledge FTO invests in its absorptive capacity. It is indisputable that, without having proper prior knowledge existing within a company, absorbing any new technological knowledge is of little benefit. As proved by the FTO case, having prior knowledge, as well as effective processes of transferring it within an organization, help the speed and frequency of innovations within a firm.

To sum up, given the fact that relatively few studies have examined in depth the relationship between absorptive capacity and organizational learning (e.g. Szulanski, 1996; Reagans \& McEvily, 2000; Tsai, 2001; Meeus et al., 2001; Oliver, 2001; Schilling, 2002; Kim \& Lee, 2002, Lao et al., 2007), we assume that our findings provide useful managerial implications referring to the importance of matching the processes of intra- and inter-firm learning. The knowledge about the available techniques and best practices in this field, as well as potential results for a company, is fundamental for several managerial decisions. Thus, in our opinion, the paper contributes to the research on learning processes within an organization. We have explored and highlighted the role of the managers' focus on finding new ways to engage employees in learning processes and to make them conscious about the importance of learning from outside the firm.

\section{CONCLUSION}

Concluding, we assess that the paper's objective has been achieved. The paper's conceptual contribution is demonstrating and exemplifying the relationships between the processes of absorptive capacity and learning lessons through employee suggestions and proposals as well as identifying potential synergies between them. The considerations, both theoretical and empirical, presented in the paper have proved that both intra- and inter-firm learning can contribute to each other and, while combined, can generate novelty that would not (never) have been achieved based on intra-firm learning or inter-firm learning alone. We have sought to answer two research questions: How do organizations apply external knowledge to support intraorganizational learning processes and employee suggestion processes in particular? And: How should the employee suggestion system be organized to increase absorptive capacity? In particular, we have been interested in studying how specific techniques and practices applied in FTO support these two aforementioned processes.

The research findings present several techniques, practices and procedures utilized by FTO to combine intra- and inter-firm learning and increase a firm's ability to create novelty, which is of high managerial 
importance. As known, a company enhances existing competences or acquires new ones by encouraging employees (both on at individual and team/group level) to learn. FTO showed a significant focus on both inter-firm learning and intra-firm learning and then on matching these two processes. Several good practices concerning acquiring new knowledge from the external sources and then assimilating and exploiting it were present in FTO and described in the paper. Also, we argue that the process of employee suggestions existing in FTO, considering its stages and course as an example of efficient intra-firm learning, is worth studying and applying in other organizations. We claim this, as the FTO case proves that such an organization of the employee suggestion system positively influences the firm's absorptive capacity. Thus, we assume that our findings provide valuable knowledge and empirical validation useful for managers making decisions concerned with building the absorptive capacity of their firms and developing the learning abilities of their organizations.

Finally, we are aware of the limitations of our study. The collected data illustrating the relationships between intra- and inter-firm learning are based on the case study of a single firm. The applied methodology of the single case study analysis enables the authors to analyze thoroughly and understand the examined issues in the given context, which is its primary advantage. However, generalizing and building theories on the basis of a single case study is almost impossible, unless it is a critical case (StrumińskaKutra \& Koładkiewicz, 2012, p. 15). In consequence, the constraints related to possibilities to build up generalizations should be listed as a limitation of the study. In order to mitigate such a limitation, the study should be replicated in the context of other organizations. Moreover, we are aware that the subject matter may include the subjectivity of opinions and interpretations. However, the presented study inspires us for in-depth investigations. According to our experience, it will be interesting to deepen the knowledge on possible techniques, practices and procedures created by other companies in the field of matching intra- and inter-firm learning. On the base of collected findings we aim to identify and describe a complex toolbox that can be used by managers to create synergy between intra-and inter-firm learning.

Applying the lens of relative absorptive capacity (Lane \& Lubatkin, 1998) to study the relationships between organizational learning and absorptive capacity is another interesting aspect to be developed in further studies. Employing the Crossan et al. (1999) model of organizational learning it is possible to "model the feed forward and feedback processes of two different companies one by one". Such a modeling enables researchers to study the extended model of 4 I (Freiling \& Fichtner, 2010) "by knowledge spill- 
overs between the two companies [and] mutual 'absorbing' processes"8. In consequence, applying the relative absorptive capacity logic to explore connections between the processes of organizational learning and absorptive capacity provides the opportunities to develop follow-up extensions of the model and potential new interpretations.

\section{Acknowledgements}

We would like to thank two anonymous reviewers for their effort, insightful comments and valuable recommendations for the improvement of the paper draft.

\section{Funding}

The project was funded by the grants of the Faculty of Economic Sciences and Management, Nicolaus Copernicus University in Toruń entitled "Przywództwo a doskonałość biznesowa w kontekście wyzwań stojących przed współczesnymi organizacjami gospodarczymi" (408/2016) and "Współczesne koncepcje zarządzania organizacjami" (501/2017) as well as the Polish National Science Centre grant on the decision number DEC-2013/11/B/HS4/00691.

\section{References}

Adams, G. L., \& Lamont, B. T. (2003). Knowledge management systems and developing sustainable competitive advantage. Journal of Knowledge Management, 7(2), 142-154.

AJP-3(B). (2011). Allied Joint Doctrine for the Conduct of Operations. Brussels: NATO Standardization Agency.

Anderson, U., Forsgren, M., \& Holm, U. (2001). Subsidiary embeddedness and competence development in MNCs - A multi-level analysis. Organizational Studies, 22(6), 1013-1034.

Autio, E., Sapienza, H. J., \& Almeida, J. G. (2000). Effects of age at entry, knowledge intensity and imitability on international growth. Academy of Management Journal, 43(5), 909-924.

Barkema, H. G., \& Vermeulen, F. (1998). International expansion through start-up or Acquisition: A learning perspective. Academy of Management Journal, 41(1), 7-26.

Barlow, J., Jashapara, A. (1998). Organizational learning and inter-firm "partnering" in the UK construction industry. The Learning Organization, 5(2), 86-98.

Beyer, K. (2011). Wiedza jako kluczowy zasób w nowej gospodarce. Studia i Prace Wydziału Nauk Ekonomicznych i Zarzqdzania, 21, 7-16.

8 The authors are grateful to the anonymous reviewer for this suggestion. 
Beyer, K. (2012). Współczesna organizacja - organizacja oparta na wiedzy. Zeszyty Naukowe Uniwersytetu Szczecińskiego, 736, 9-25.

Burley, D. L., \& Pandit, G. (2008). Lessons learned: Organizational realities influence KMS implementation. VINE: The Journal of Information and Knowledge Management Systems, 38(4), 476-489.

Child, J., Faulkner, D., \& Tallman, S. B. (2005). Cooperative Strategy: Managing Alliances, Networks and Joint Ventures. Oxford: Oxford University Press.

Cohen, W. M., \& Levinthal, D. A. (1990). Absorptive capacity: A new perspective on learning and innovation. Administrative Science Quarterly, 35(1), 128152.

Crisculo, P., \& Narula, R. (2008). A novel approach to national technological accumulation and absorptive capacity: Aggregating Cohen and Levinthal. European Journal of Development Research, 20(1), 56-73.

Crossan, M. M., Lane, H. W., \& White, R. E. (1999). An organizational learning framework: From intuition to institution. Academy of Management Review, 24(3), 522-537.

Crossan, M. M., \& Berdrow, I. (2003). Organizational learning and strategic renewal. Strategic Management Journal, 24(11), 1087-1105.

Czerniachowicz, B. (2003). Organizacja ucząca się a organizacja inteligentna. In: D. Kopycińska (Ed.), Kapitał ludzki w gospodarce (pp. 39-51). Szczecin: Uniwersytet Szczeciński.

Daghfous, A. (2004). Organizational learning, knowledge and technology transfer: A case study. The Learning Organization, 11(1), 67-83.

Dodgson, M. (1993). Organizational learning: A review of some literatures. Organization Studies, 14(3), 375-394.

Davidson, M. N., \& James, E. H. (2007). The engines of positive relationships across difference: Conflict and learning. In: J.E. Dutton \& B.R. Ragins (Eds.), Exploring Positive Relationships at Work: Building a Theoretical and Research Foundation (pp. 137-158). New York: Lawrence Erlbaum.

Davenport, T. H., \& Prusak, L. (2000). Working Knowledge: how Organizations Manage What They Know. Boston: Harvard Business School Press.

De Geus, A. (1988). Planning as learning. Harvard Business Review, 20(2), 7074.

Duchek, S. (2013). Catching absorptive capacity: A critical review and future prospects. Schmalenbach Business Review, July, 312-329.

Ekval, G. (1971). Creativity at the Place of Work. Stockholm: Reklamlito.

Ekvall, G. (1996). Organizational climate for creativity and innovation. European Journal of Work and Organizational Psychology, 5(1), 105-123.

Easterby-Smith, M., Graça, M., Antonacopoulou, E., \& Ferdinand, J. (2008). Absorptive capacity: A process perspective. Management Learning, 39(5), 483-501.

Edmondson, A. C. (2007). The competitive imperative of learning. Harvard Business Review, 86(7-8), 60-67. 
Fairbank, J. F., \& Williams, S. D. (2001). Motivating creativity and enhancing innovation through employee suggestion system technology. Creativity and Innovation Management, 10(2), 68-74.

Fiol, C. M., \& Lyles, M. A. (1985). Organizational learning. Academy of Management Review, 10(4), 803-813.

Foley, R. T., Griffin, S., \& McCartney, H. (2011). 'Transformation in contact': Learning the lessons of modern war. International Affairs, 87(2), 253270.

Freiling, J., \& Fichtner, H. (2010). Organizational culture as the glue between people and organization: A competence-based view on learning and competence building. Zeitschrift fur Personalforschung, 24(2), 152-172.

Garvin, D. A. (1993). Building a learning organization. Harvard Business Review, 71(4), 78-91.

Girard, J. (2004). Defence knowledge management: A passing fad? Canadian Military Journal, Summer, 17-23.

Goleman, D., Boyatzis, R., \& McKee, A. (2001). Primal leadership: The hidden driver of great performance. Harvard Business Review, 79(11), 42-51.

Haider, S. (2003). Inter-firm and intra-firm organizational learning and knowledge processes: Sequence and interrelatedness. Retrieved from http://www2.warwick.ac.uk/fac/soc/wbs/conf/olkc/archive/oklc5/ papers/a-6_haider.pdf

Hardagon, A., \& Sutton, R. I. (2000). Building an innovation factory. Harvard Business Review, 78(3), 157-166.

Heath, J. (2015). Methodological individualism. In: N. Zalta (Ed.), The Stanford Encyclopedia of Philosophy. Retrieved from https://plato.stanford.edu/ entries/methodological-individualism/

Hedberg, B. L. T. (1981). How organizations learn and unlearn. In: P.C. Nystrom \& W.H. Starbuck (Eds.), Handbook of Organizational Design: Vol. 1. Adapting Organizations to Their Environments (pp. 3-27). New York: Oxford University Press.

Historia firmy (nd). Retrieved from http://frauenthal-automotive.pl/historiafirmy

Holmqvist, M. (1999). Learning in imaginary organizations: Creating interorganizational knowledge. Journal of Organizational Change Management, 12(5), 419-438.

Holmqvist, M. (2000). The dynamics of experiential learning: Balancing exploitation and exploration within and between organizations, School of Business Research Report No. 12. Stockholm: Stockholm University, School of Business.

Huber, G. P. (1991). Organizational learning: The contributing processes and the literatures. Organization Science, 2(1), 88-115.

Imai, M. (2012). Gemba kaizen: A Commonsense Approach to a Continuous Improvement Strategy. New York: McGraw Hill.

Isaken, S. G., Lauer, K. J., Ekvall, G., \& Britz, A. (2001). Perceptions of the best and worst climates for creativity: Preliminary validation evidence 
for situational outlook questionnaire. Creativity Research Journal, 13(2), 171-184.

Jabłoński, J., Lis, A. (2012). Lessons learned system as a tool of managing organisational knowledge: The case of military organisations. In: A. Nalepka \& A. Ujwary-Gil (Eds.), Business and Non-Profit Organizations Facing Increased Competition and Growing Customers' Demands (Vol. 11, pp. 163-186). Nowy Sącz: Wyższa Szkoła Biznesu - National Louis University.

Jansen, J. J. P., Van Den Bosch, F. A. J., \& Volberda, H. W. (2005). Managing potential and realized absorptive capacity: How do organizational antecedents matter? Academy of Management Journal, 48(6), 999-1015.

Jashapara, A. (2004). Knowledge Management: An Integrated Approach. London: Prentice Hall.

Jaskanis, A. (2016). Organizacyjne uczenie się i zarządzanie wiedzą. In: K. Klincewicz (Ed.), Zarzqqdzanie, organizacje i organizowanie - przeglad perspektyw teoretycznych (pp. 491-501). Warszawa: Wydawnictwo Naukowe Wydziału Zarządzania Uniwersytetu Warszawskiego.

Jonassen, D., \& Land, S. (Eds.) (2012). Theoretical Foundations of Learning Environments, New York: Routledge.

Kazojć, K. (2013). Transfer wiedzy a kultura inteligentnych porażek w przedsiębiorstwie innowacyjnym. Zeszyty Naukowe Wyższej Szkoły Bankowej w Poznaniu, 51(6), 71-86.

Kim, L. (1998). Crisis construction and organizational learning: Capability building in catching-up at Hyundai Motor. Organization Science, 9(4), 506-521.

Kim, Y., \& Lee, B. (2002). Patterns of technological learning among the strategic groups in the Korean electronic parts industry. Research Policy, 31(4), 543-567.

Kincaid, H. (2004). Methodological individualism and economics. In: J.B. Davis, A. Marciano, \& J. Runde (Eds.), The Elgar Companion to Economics and Philosophy (pp. 299-314). Cheltenham: Edward Elgar.

Lane, P. J., Koka B. R., \& Pathak, S. (2006). Reification of absorptive capacity: A critical review and rejuvenation of the construct. Academy of Management Review, 31(4), 833-863.

Lane, P. J., \& Lubatkin, M. (1998). Relative absorptive capacity and interorganizational learning. Strategic Management Journal, 19(5), 461477.

Larsson, R., Bengtsson, L., Henriksson, K., \& Sparks, J. (1998). The interorganizational learning dilemma: Collective knowledge development in strategic alliances. Organization Science, 9(3), 285-305.

Liao, S. H., Fei, W. C., \& Chen, C. C. (2007). Knowledge sharing, absorptive capacity and innovation capability: An empirical study of Taiwan's knowledge-intensive industry. Journal of Information Science, 33(3), 340-359. 
Lichtenthaler, U. (2009). Absorptive capacity, environmental turbulence, and the complementarity of organizational learning processes. Academy of Management Journal, 52(4), 822-846.

Lis, A. (2012a). Positive organizational behaviors as the key success factors for lessons learned systems: The case of military organizations. Journal of Positive Management, 3(1), 82-93.

Lis, A. (2012b). How to strengthen positive organizational behaviors fostering experiential learning: The case of military organizations. Journal of Entrepreneurship, Management and Innovation, 8(4), 21-34.

Lis, A. (2014a). Knowledge creation and conversion in military organizations: How the SECl model is applied within armed forces. Journal of Entrepreneurship, Management and Innovation, 10(1), 57-78.

Lis, A. (2014b). Kulturowe uwarunkowania pozytywnych zachowań organizacyjnych w systemie wykorzystania doświadczeń. In W. Kieżun, J. Wołejszo \& T. Całkowski (Eds.), Public Management 2014: Innowacyjność w procesach zarzqdzania i dowodzenia organizacjami publicznymi (pp. 187-198). Warszawa: Akademia Obrony Narodowej.

Lis, A. (2016). Paradoksy organizacyjnego uczenia się na przykładzie procesów wykorzystania doświadczeń. Organizacja i Kierowanie, 2, 61-71.

Lis, A., \& Sudolska, A. (2015). Absorptive capacity and its role for the company growth and competitive advantage: The case of Frauenthal Automotive Torun company. Journal of Entrepreneurship, Management and Innovation, 11(4), 63-91.

Mäkinen, H. (2002). Intra-firm and inter-firm learning in the context of startup companies. Entrepreneurship and Innovation, 3(1), 35-43.

Marksberry, Ph., Church, J., \& Schmidt, M. (2014). The employee suggestion system: A new approach using latent semantic analysis. Human Factors and Ergonomics in Manufacturing \& Service Industries, 24(1), 29-33.

Meeus, M. T. H., Oerlemans, L. A. G., \& Hage, J. (2001). Patterns of interactive learning in a high-tech region. Organizational Studies, 22(1), 145-172.

Milton, N. (2010). The Lessons Learned Handbook: Practical Approaches to Learning from Experience. Oxford: Chandos Publishing.

Mohr, J. J., \& Sengupta, S. (2002). Managing the paradox of inter-firm learning: The role of governance mechanisms. Journal of Business \& Industrial Marketing, 17(4), 282-301.

Mowery, D. C., Oxley J. E., \& Silverman, B. S. (1996). Strategic alliances and interfirm knowledge transfer. Strategic Management Journal, 17(S2), 7791.

Nag, R., \& Gioia, D. A. (2012). From common to uncommon knowledge: Foundations of firm-specific use of knowledge as a resource. Academy of Management Journal, 55(2), 421-457.

Narula, R. (2003). Understanding absorptive capacities in an 'innovation systems' context: Consequences for economic and employment growth. DRUID Working Paper No. 04-02, Danish Research Unit for Industrial Dynamics. 
Neagoe, L. N., \& Marascu Klein, V. (2010). Employee suggestion system (kaizen teian): The bottom-up approach for productivity improvement. Recent, 10(3), 361-366.

Newstrom, J. W. (1983). The management of unlearning: Exploding the 'clean slate' fallacy. Training and Development Journal, 37(8), 36-39.

Noblet, J. P., Simon, E., \& Parent, R. (2011). Absorptive capacity: A proposed operationalization. Knowledge Management Research and Practice, 9, 367-377.

Nonaka, I., \& Konno, N. (1998). The concept of 'Ba': Building a foundation for knowledge creation. California Management Review, 40(3), 40-54.

Nonaka, I., \& Takeuchi, H. (1995). The Knowledge Creating Company. New York: Oxford University Press.

Nonaka, I., Toyama, R., \& Konno, N. (2000). SECl, Ba and leadership: A unified model of dynamic knowledge creation. Long Range Planning, 33, 5-34.

Olejniczak, K., Płoszaj, A., \& Rok, J. (2012). Organizacyjne uczenie się i zarządzanie wiedzą - przegląd koncepcji. In: K. Olejniczak (Ed.), Organizacje uczqce się: Model dla administracji publicznej (pp. 61-107). Warszawa: Wydawnictwo Naukowe Scholar.

Oliver, A. L. (2001). Strategic alliances and the learning lifecycle of biotechnology firms. Organization Studies, 22(3), 467-489.

Olszewska, B. (2013). Teoretyczne nurty dominujące w problematyce uczenia się organizacji. Prace Naukowe Uniwersytetu Ekonomicznego we Wrocławiu, 310, 15-31.

Palakshappa, N., \& Gordon, M. E. (2007). Collaborative business relationships: Helping firms to acquire skills and economies to prosper. Journal of Small Business and Enterprise Development, 14(2), 264-279.

Patton, E., \& Appelbaum, S. H. (2003). The case for case studies in management research. Management Research News, 26(5), 60-71.

Reagans, R., \& McEvily, B. (2000). Network structure and knowledge transfer: The effects of cohesion and range. Administrative Science Quarterly, 48(2), 240-267.

Rhodes, J., Lok, P., Yu-Yuan Hung, R., \& Fang, S. C. (2008). An integrative model of organizational learning and social capital on effective knowledge transfer and perceived organizational performance. Journal of Workplace Learning, 20(4), 245-258.

Rowe, W. G., \& Guerrero, L. (2011). Cases in Leadership. Thousand Oaks: Sage Publications.

Schilling, M. A. (2002). Technology success and failure in winner-takeall markets: The impact of learning orientation, timing and network externalities. Academy of Management Journal, 45(2), 387-398.

Schein, E. H. (2004). Organizational Culture and Leadership. San Francisco: John Wiley \& Sons.

Stake, R. E. (2010). Jakościowe studium przypadku. In N. K. Denzin, \& Y. S. Lincoln (Eds.), Metody badań jakościowych (Vol. 1, pp. 623-654). Warszawa: PWN. 
Strumińska-Kutra, M., \& Koładkiewicz, I. (2012). Studium przypadku. In D. Jemielniak (Ed.), Badania jakościowe: Metody i narzędzia (Vol. 2, pp. 1-40). Warszawa: PWN.

Sudolska, A., \& Lis, A. (2014). Building a model of successful collaborative learning for company innovativeness. Journal of Entrepreneurship, Management and Innovation, 10(3), 109-137.

Sun, P. Y. T., \& Anderson, M. H. (2010). An examination of the relationship between absorptive capacity and organizational learning, and a proposed integration. International Journal of Management Reviews, 12(2), 130150.

Szulanski, G. (1996). Exploring internal stickiness: Impediments to the transfer of best practices within the firm. Strategic Management Journal, 17(S2), 27-43.

Todorova, G., \& Durisin, B. (2007). Absorptive Capacity: Valuing a reconceptualization. Academy of Management Review, 32(3), 774-786.

Trott, P. (2008). Innovation Management and New Product Development. Harlow: Prentice Hall.

Tsai, W. (2001). Knowledge transfer in intraorganizational networks: Effects of network position and absorptive capacity on business unit innovation and performance. Academy of Management Journal, 44(5), 996-1004.

Van den Bosch, F. A. J., Volberda, H. W., \& De Boer, M. (1999). Coevolution of firm absorptive capacity and knowledge environment: Organizational forms and combinative capabilities. Organization Science, 10(5), 551568.

Van Dijk, Ch., \& van den Ende, J. (2002). Suggestion systems: Transferring employee creativity into practicable ideas. $R \& D$ Management, 32(5), 387-395.

Vera, D., \& Crossan, M. (2004). Strategic leadership and organizational learning. Academy of Management Review, 29(2), 222-240.

Weber, R. O., \& Aha, D. W. (2003). Intelligent delivery of military lessons learned. Decision Support Systems, 30(3), 287-304.

Weick, K. E. (1995). Sensemaking in Organizations. Thousand Oaks: SAGE.

Yin, R.K. (2010). Designing case studies. In M. Frenz, K. Nielsen, \& G. Walters (Eds.), Research Methods in Management (pp. 185-226). London: SAGE.

Yli-Renko, H. (1999). Dependence, Social Capital, and Learning in Key Customer Relationships: Effects on the Performance of Technology-Based New Firms. Espoo: The Finnish Academy of Technology.

Zahra, S.A., \& George, G. (2002). Absorptive capacity: A review, reconceptualization, and extention. Academy of Management Review, 27(2), 185-203. 


\begin{abstract}
Polish)
Celem artykułu jest zbadanie relacji pomiędzy procesami absorpcji wiedzy zewnętrznej (międzyorganizacyjne uczenie się) oraz uczeniem się z doświadczeń poprzez system sugestii pracowniczych (wewnq̨trzorganizacyjne uczenie się). Uwaga została skierowana na zbadanie następujq̨cych problemów: (1) W jaki sposób organizacje wykorzystuja wiedzę zewnętrzna do wsparcia procesów wewnątrzorganizacyjnego uczenia się, a w szczególności procesów wykorzystania doświadczeń na podstawie sugestii pracowniczych? (2) W jaki sposób zorganizować system sugestii pracowniczych aby wzmocnić zdolność organizacji do absorpcji wiedzy zewnętrznej? Do rozwiqzania wskazanych powyżej problemów badawczych zastosowano podejście eksploracyjne bazujqce na metodzie studium przypadku. Jednostkq analizy były procesy międzyorganizacyjnego $i$ wewnątrzorganizacyjnego uczenia się w przedsiębiorstwie Frauenthal Automotive Toruń (FTO).
\end{abstract}

Słowa kluczowe: organizacyjne uczenie się; zdolność organizacji do absorpcji wiedzy zewnętrznej; systemy wykorzystania doświadczeń; systemy sugestii pracowniczych.

\title{
Biographical notes
}

Andrzej Lis, Ph.D. is an Assistant Professor in the Department of Business Excellence, the Faculty of Economic Sciences and Management, Nicolaus Copernicus University, Toruń. Since 2013, he has been the executive editor of the Journal of Corporate Responsibility and Leadership (JCR\&L). His area of research activity encompasses the issues of knowledge management, change management, leadership, the defence industry and military logistics, whereas the main research interest is focused on Lessons Learned processes. In 2017, Andrzej Lis was awarded for the best keynote speech at the U.S. Joint Lessons Learned Conference in Suffolk, VA and for the best paper at the 9th Organization Development Management Conference (Konferencja "Zarządzanie Rozwojem Organizacji") organized by Łódź University of Technology. Contact: andrzejlis@econ.umk.pl.

Prof. Agata Sudolska, Ph.D. works at the Faculty of Economic Sciences and Management, Department of Enterprise Management, Nicolaus Copernicus University in Torun. Her research interests comprise innovation management with a particular focus on responsible innovation approach and businessto-business relations management. She has worked on several research, scientific and educational projects related to pro-innovative inter-firm relationships management, creating pro-innovative organizational climate, and social innovations issues. Contact: aga@econ.uni.torun.pl. 
